\title{
PARAFRASA DALAM TERJEMAHAN NOVEL PEEBEE HAS A WISH
}

\author{
Arif Hidayat dan Danang Dwi Harmoko
}

Program Studi Sastra Inggris, STIBA Nusa Mandiri

Jalan Ir. H. Juanda Nomor 39 Ciputat, Tangerang Selatan, Banten

Surel: arif.aft@nusamandiri.ac.id

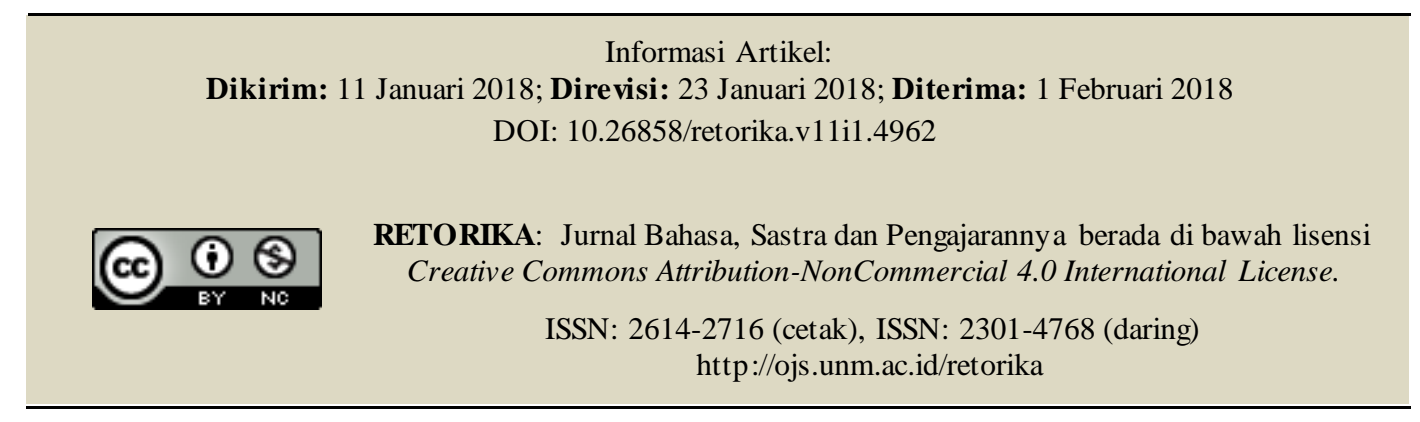

\begin{abstract}
Paraphrases in the Novel Translation Peebee Has a Wish. This study is aimed at giving explanation of how paraphrase is used in the process of translation by translator in a literary work Harapan Peebee from its original version 'Peebee Has A Wish' based on the theory of Danielsson which divide the level of equivalence on the lexical, phrase and grammar alternatives . This study uses descriptive qualitative method. The result shows that the three alternatives categories are found in the translation. Meanwhile, phrase category dominates the findings. However, there are many findings tell the overrated paraphrases where one utterance or sentence are inhabited by more than one alternatives or even all of the categories mentioned by Danielsson.

Abstrak: Parafrasa dalam Terjemahan Novel Peebee Has a Wish. Penelitian ini bertujuan menguraikan bentuk parafrasa yang digunakan dalam proses penerjemahan oleh penerjemah dalam karya sastra Harapan Peebee yang merupakan karya terjemahan dari buku cerita Peebee Has a Wish. Dengan menggunakan teori Danielsson yang membedakan tingkatan kesepadanan pada alternatif leksikal, frasa dan tata bahasa, penelitian ini bersifat deskriptif dengan metode kualitatif. Hasilnya menunjukkan bahwa terdapat tiga kategori alternatif yang muncul pada terjemahanm yang didominasi oleh alternatif frasa. Di sisi lain, ada temuan-temuan yang menunjukkan adanya gabungan alternatif dalam satu kalimat atau ujaran.
\end{abstract}

Kata Kunci: parafrasa, Harapan Peebee, leksikal, penerjemahan 
Terjemahan yang baik tentunya akan menjadi pertimbangan yang sangat penting dalam memilih bahan bacaan terjemahan. Apalagi bacaan tersebut merupakan bahan bacaan yang penuh dengan ekspresi dan menggali imajinasi, seperti karya sastra. Karya sastra merupakan hasil pemikiran, pengalaman, dan perasaan dari sang penulis. Karya ini lebih mengedepankan peran hiburan bagi para pembacanya, berbeda dengan karya tulis lain, seperti karya tulis ilmiah.

Penerjemahan karya sastra yang tidak baik akan menghilangkan seni, nilai, dan ekspresi yang ada dalam karya sastra. Wechsler (1998) menyatakan bahwa penerjemahan karya sastra merupakan seni yang unik. Penerjemahan melibatkan orang yang duduk di balik meja dan menuliskan karya sastra yang bukan miliknya. Tugas penerjemah ini adalah memunculkan komposisi penulis aslinya dan mengungkapkannya dengan caranya sendiri. Wechsler menyebut penerjemahan ini sebagai seni dan penerjemahnya sebagai performer without stage, yakni pelaku sandiwara yang memainkan peran seninya tanpa ada panggung yang tersedia. Media yang dipakainya adalah pengungkapan kembali karya asli dengan caranya.

Penerjemah karya sastra harus dapat menangkap isi pesan yang disampaikan oleh penulis naskah asli. Ia harus mampu menganalisa makna maksud yang terkandung di dalam karya sastra dan mengungkapkannya kembali dengan baik. Darma (2007) yang mengutip Hatim dan Mason mengemukakan bahwa ada beberapa aspek dalam tugas yang diemban penerjemah, yakni (1) mengenai pemahaman teks sumber, seorang penerjemah harus mampu mengurai teks, baik tata bahasa maupun kosakata yang terdapat di dalamnya. Dia juga harus menggali pengetahuan terkait dengan teks dan tentunya memahami makna yang dimaksudkan oleh penulis teks sumber; (2) Dalam pengalihan makna, penerjemah harus bisa memakai makna leksikal, menggunakan makna gramatikal, dan memanfaatkan makna retoris termasuk makna tersirat; dan (3) Seorang penerjemah juga harus dapat memiliki penilaian terhadap teks sasaran, yaitu keterbacaan, penyerasian dengan konvensi umum dan wacana, dan menimbang kememadaian terjemahan demi tujuan tertentu.

Hoed (2006) menyatakan bahwa penerjemahan adalah kegiatan tertulis dalam mengalihkan pesan dari teks suatu bahasa ke dalam teks bahasa lain. Di sini, seperti halnya Newmark
(1988), Hoed berfokus pada penerjemahan pesan. Nida (1964) lebih jauh lagi dalam memaknai bahwa penerjemahan adalah upaya untuk mencapai kesepadanan dalam kategori formal dan dinamis. Kategori formal yang diungkapkan Nida merupakan kesepadanan secara bentuk dan isi dari teks sumber, sedangkan kesepadanan dinamis adalah tercapainya isi pesan teks sumber yang menekankan pada respon yang didapat teks sasaran sama dengan respon yang diberikan pembaca teks sumber. Perbedaan-perbedaan pada fokus ini pada akhirnya tertuju pada sampainya pesan yang disampaikan oleh penulis dalam Bahasa Sumber (BSu) kepada pemahaman pembaca dalam Bahasa Sasaran (BSa) yang menerimanya secara wajar.

Salah satu permasalahan penerjemahan yang biasa dihadapi adalah permasalahan pemahaman. Nord (1991) memberikan permasalahan penerjemahan dan prosedur dalam tabel analisis teks dan skopos translation. Dalam tabel tersebut, terdapat faktor-faktor intratekstual yang di antaranya istilah budaya, pembagian ke dalam beberapa paragraf atas kalimat yang panjang dan mempermudah struktur kalimat. Oleh Karena itu, perlu ada prosedur yang dapat menyelesaikan masalah ini. Newmark (1998) memberikan beberapa prosedur penerjemahan untuk menggapai terjemahan yang terdekat dengan pesan, yakni analisis komponen, modulasi, kesetaraan deskriptif, kesetaraan fungsional, kesetaraan budaya, sinonimi, dan parafrasa.

Novel sebagai salah satu karya sastra memerlukan tidak hanya kemampuan pemahaman bacaan secara leksikal, tetapi juga pragmatik dan kontekstual. Pemahaman ini mengarah ke penerjemahan komunikatif yang diungkapkan oleh Newmark (1991) bahwa terjemahan ini mementingkan pembaca sasaran, berorientasi pada efek, mengadaptasi pemikiran dan budaya agar lebih diterima pembaca sasaran, mudah dibaca pembaca sasaran, bertujuan menyenangkan, dapat terjadi bias bahasa sasaran, berorientasi pesan bukan pada makna. Menerjemahkan karya sastra sesuai dengan apa yang telah disampaikan Newmark di atas membawa orientasi pada isi dan efek yang akan didapat oleh pembaca bahasa sasaran menjadi sangat penting. Berbagai teknik, strategi, dan prosedur penerjemahan telah diungkapkan oleh berbagai ahli penerjemahan. Dari berbagai prosedur, parafrasa adalah salah satu prosedur penerjemahan (Newmark, 1998). Prosedur ini dipilih sebagai fokus dalam penelitian ini. 
Kegiatan penerjemahan dipengaruhi oleh klien dan pembaca sehingga menyebabkan keterbacaan menjadi unsur penting dalam dalam proses penerjemahan (Nababan, 2003). Sebagai prosedur penerjemahan, parafrasa dapat membantu penerjemah dalam memberikan isi dari pesan yang ingin disampaikan dengan memakai bahasa yang biasa digunakan oleh penerjemah sendiri. Apalagi dalam penerjemahan karya sastra, jenis penerjemahan ini membutuhkan gaya bahasa yang tidak kaku. Daneilsson (2007:2) bahkan dengan terang menyatakan bahwa penerjemahan telah sering dirujuk sebagai seni memparafrasa teks dari suatu bahasa ke bahasa yang lain. Ungkapan Danielsson ini memberikan penguatan mengenai peran dan fungsi parafrasa dalam proses penerjemahan yang bukan hanya sebagai salah satu strategi, prosedur maupun teknik dalam menerjemahkan. Danielsson memandang penerjemahan itu sendiri merupakan 'seni penerjemahan'. Kemudian, Danielsson menyatakan bahwa ada lebih dari satu cara untuk memparafrasa suatu pernyataan. Pilihan cara ini kemudian diserahkan kepada penerjemah itu sendiri.

Perihal penerjemaham yang disampaikan di atas menjadi salah satu kesimpulan Danielsson setelah bertahun-tahun memiliki pertanyaan mengenai penggunaan parafrasa otentik pada penerjemahan. Lebih lanjut, dia memberikan definisi sederhana dari parafrasa. Dia menyatakan bahwa parafrasa merupakan suatu penyampaian suatu pernyataan, frasa, atau satu kata dengan memakai kata-kata yang lain (Danielsson, 2007:3). Dari pernyataan sederhana ini, dia merujuk bahwa parafrasa merupakan hal sama yang berbeda. Ada satu ide yang disampaikan oleh seseorang, kemudian disampaikan ulang dengan kata-kata yang berbeda atau gaya bahasa yang berbeda oleh orang lain tanpa mengurangi makna atau efek yang ingin disampaikan. Di sini, dapat dimaknai bahwa parafrasa, termasuk yang dipakai dalam penerjemahan dapat dilihat penyampaian yang berbeda dari pernyataan, frasa atau kata (terjemahan harfiahnya).

Berdasarkan penelitiannya pada korpus data berbagai terjemahan dari sumber yang sama, Danielsson menemukan tiga kategori penggunaan parafrasa dalam penerjemahan. Kategori tersebut adalah leksis alternatif, frasa alternatif, dan tata bahasa alternatif. Leksis alternatif, menurutnya, merupakan bentuk paling sederhana yaitu penggantian satu kata dengan kata lain atau dengan kombinasi dari beberapa kata. Sebagai contoh,
Danielsson (2007:7) menyatakan bahwa kata hear yang berarti 'mendengar' dapat digantikan dengan kata listen atau dengan frasa listen to yang dalam bahasa Indonesia berarti "menyimak'. Penggunaan indera yang sama mungkin dapat menjadi satu alasan kata listen dapat menggantikan kata hear.

Di sisi lain, frasa alternatif merupakan penggantian sekumpulan kata dengan kata yang lain dalam satu ide yang sama. Meskipun menggunakan kata frasa, namun penggunaannya di sini bukan hanya merujuk pada kumpulan dua kata atau lebih yang memiliki makna tertentu dan merupakan bagian yang membentuk klausa atau kalimat selayaknya frasa pada umunya. Alternatif frasa ini juga dapat merujuk pada klausa itu sendiri dalam sebuah kalimat majemuk. Danielsson (2007:8) memberikan contoh kumpulan kata/ klausa let us hear yang berarti 'mari kita dengar'. Klausa ini dapat digantikan dengan continue to explain yang memiliki arti 'lanjutkan menjelaskan' atau menggunakan alternatif 'silakan lanjutkan penjelasannya'. Penggantian ini menyiratkan adanya ilokusi atau maksud terntentu yang sama yang ingin disampaikan oleh penutur pada orang yang diajak bicara. Efek atau reaksi dari tuturan yang diharapkan tersebut pun tidak berbeda.

Kedua alternatif yang disebutkan awal di atas berbeda dalam kuantitas kata di awal. Leksis alternatif difungsikan untuk menggantikan satu kata dengan satu kata juga atau frasa. Di sisi lain, frasa alternatif menggantikan kumpulan kata, termasuk frasa dan/atau klausa yang terdapat dalam satu kalimat majemuk. Berbeda lagi dengan tata bahasa alternatif. Alternatif yang satu ini terletak pada sisi tata bahasa. Tata bahasa alternatif kategori digunakan saat kedua kalimat yang diperbandingkan berbeda dalam konteks tata bahasa (Danielsson, 2007:9). Sebagai contoh, klausa what he saw before was an illsion digantikan dengan what he'd seen before was incense. Dalam bahasa Indonesia, what he saw before berarti 'apa yang dia lihat sebelumnya' (pada satu waktu di masa lampau). Pengganti, meskipun berarti 'apa yang pernah dia lihat' juga berada di masa lampau, namun penggunaan had seen memiliki makna kejadian yang terjadi sebelum satu kejadian lainnya di masa lampau. Kala waktu yang merupakan bagian dari tata bahasa di sini menjadi satu contoh bagaimana tata bahasa alternatif dapat terjadi.

Dari uraian di atas, penelitian ini bertujuan mengungkap penggunaan parafrasa dalam terje- 
mahan Novel Peebee Has A Wish yang diterjemahkan ke dalam Novel Harapan Peebee yang ditujukan bagi anak-anak. Menerjemahkan karya sastra bukan merupakan hal yang mudah karena banyak memusatkan perhatian pada pembaca sasaran. Terlebih lagi, buku cerita Harapan Peebee yang merupakan buku terjemahan dari Peebee Has A Wish merupakan terjemahan karya sastra yang dikhususkan bagi anak-anak yang secara umum masih sangat perlu diperhatikan masalah pemilihan kata dan masalah keterbacaannya. Perhatian hasil terjemahan yang dikhususkan bagi pembaca, khususnya anak-anak, bukanlah suatu hal yang mudah. Terlebih lagi, terjemahan yang baik seharusnya tidak terlihat sebagai hasil terjemahan. Penerjemahan karya sastra, khususnya untuk anak-anak, harusnya dapat menjadi bacaan yang menghibur, bukan bacaan yang membuat pembacanya berpikir keras dan terbebani.

\section{METODE}

Penelitan ini didesain dengan penelitian deskriptif kualitatif. Data berupa berbagai kalimat dan dialog yang teridentifikasi sebagai terjemahan yang mengalami parafrasa dengan rujukan pengategorian yang diberikan oleh Danielsson (2007). Sumber data dalam penelitian ini adalah buku cerita yang berbahasa Inggris sebagai bahasa sumber (BSu) dan buku berbahasa Indonesia sebagai bahasa sasaran. Buku Peebee Has A Wish sebagai teks sumber merupakan karangan Rudi Corens yang diterbitkan tahun 2007 oleh Erlangga For Kids, sedangkan Harapan Peebee merupakan buku yang diterjemahkan oleh Faisal Riyadi dan Redy Kuswanto dan dikeluarkan tahun 2008 oleh penerbit yang sama.

Data dalam penelitian ini adalah teks terjemahan dari bahasa sasaran yang dibandingkan dengan teks dari bahasa sumber yang diindikasikan telah mendapat parafrasa dalam hasil terjemahannya, bukan terjemahan harfiah. Bahasa sumber dari penelitian ini adalah bahasa Inggis, sedangkan bahasa sasaran adalah bahasa Indonesia. Data yang didapat kemudian dikumpulkan dan dikategorikan berdasarkan kategori alternatif parafrasa, meliputi leksis, frasa, dan tata bahasa Danielsson (2007). Untuk memudahkan pengategorian digunakan format analisis di Tabel 1.

Data yang sudah terindikasi mengalami parafrasa dimasukkan ke dalam kolom-kolom data (Tabel 1). Dengan melihat ciri-ciri data, pe- neliti kemudian mengamati secara mendalam dan mengkategorikannya dengan tanda centang pada kolom kategori masing-masing. Selain melihat ciri-cirinya, peneliti juga mengamati kemungkinan hasil terjemahan menjadi seperti yang tercetak, bukan seperti terjemahan harfiah. Karena penelitian ini bersifat kualitatif, pengamatan dilakukan berulang-ulang hingga menemukan titik jenuh. Temuan dari penelitian ini diulas dalam pembahasan pada bagian selanjutnya secara komprehensif berdasarkan kategori-kategori yang telah dijelaskan di atas.

Tabel 1. Matriks Kategori Alternatif Parafrasa

\begin{tabular}{cccc}
\hline & & \multicolumn{2}{c}{$\begin{array}{c}\text { Kategori Alternatif } \\
\text { Parafrasa }\end{array}$} \\
\cline { 3 - 4 } No & Data & Leksis & Frasa $\begin{array}{l}\text { Tata } \\
\text { Bahasa }\end{array}$ \\
\hline 1 & & Data 1 & $\sqrt{ }$ \\
2 & Data 2 & & $\sqrt{ }$ \\
\hline
\end{tabular}

\section{HASIL DAN PEMBAHASAN}

Dalam terjemahan Novel anak Peebee Has A Wish, ditemukan banyak kalimat terjemahan yang memakai unsur prosedur parafrasa. Temuan penelitian dibagi menjadi empat kategori: alternatif leksis, alternatif frasa, alternatif tata bahasa, dan alternatif gabungan. Hasil penelitian diuraikan sebagai berikut.

\section{Alte rnatif Leksikal}

Terdapat banyak alternatif leksikal yang terjadi seperti contoh-contoh di bawah ini. Alternatif leksikal yang terjadi dapat berupa dari leksis ke leksis, maupun dari leksis ke frasa, seperti contoh-contoh di bawah ini.

(1) ... But what they did not say was that there was one Biggle-Boggle tree in Razzelmazzeland which was much taller than any other Biggle-Boggle tree in the whole of Razzel-mazzelland.

... Hanya saja, mereka tidak mengatakan kalau di Negeri Razel-mazzel terdapat satu pohon Biggle-Boggle yang jauh lebih tinggi dan besar dari pohon Biggle-Boggle lain yang tumbuh di Negeri Razzel-mazzel.

Pada data (1), kata but yang secara harfiah seharusnya diterjemahkan sebagai 'tetapi' yang merupakan terjemahan harfiahnya. Penerjemah 
lebih memilih menerjemahkan kata but dengan 'hanya saja'. Makna yang terkandung dalam kata 'tetapi' mengindikasikan kata hubung yang memiliki maksud mempertentangkan antara satu ide dengan ide lainnya dalam satu tulisan. Di lain sisi, frasa 'hanya saja' sebagai pengganti kata 'tetapi' juga memiliki makna yang tidak berbeda. Oleh karena itu, penggunaan frasa 'hanya saja' dianggap lebih baik dari sekedar kata 'tetapi', namun dengan efek pertentangan yang sama.

Contoh lain dari alternatif leksis dengan mengganti kata dengan frasa dapat terlihat dari terjemahan kata yang terdapat pada data berikut ini.

\section{(2) But that is a story for later.}

Tapi, itu cerita untuk lain waktu.

Data (2) menunjukkan bahwa pada bahasa sumber, kata later bermakna 'nanti'. Penerjemah memilih untuk tidak menerjemahkannya secara harfiah. Frasa 'lain waktu' lebih dipilih dibanding terjemahan harfiah 'nanti'. Secara makna, 'lain waktu' menandakan waktu yang akan datang, tetapi tidak tentu. Hal ini sama juga dengan makna yang terkandung dalam kata 'nanti'.

Selain penggantian pemilihan kata/leksis dari terjemahan sebenarnya yang berbentuk frasa, bentuk kata yang diganti dengan kata juga terdapat pada data (3) dan (4) berikut.

(3) "... That was indeed much shorter name and much easier to remember."

“... Nama itu memang jauh lebih pendek dan mudah diingat."

Pada data (3), kata that diterjemahkan menjadi 'nama' dalam bahasa sasaran. Padahal, dalam bahasa Indonesia, kata that berarti 'itu' jika diterjemahkan secara harfiah. Akan tetapi, kata 'itu' dalam bahasa sasaran atau that dalam bahasa sumber merupakan kata yang merujuk pada kata yang sebelumnya telah disebutkan, yaitu Peepabibibooga. Kata yang dirujuk adalah nama dari satu tokoh dalam cerita. Kata 'itu' atau that tersebut merujuk pada suatu nama sehingga menjadi alasan pemilihan alternatif leksis dari 'nama' dalam bahasa sasaran.

Temuan lain ditunjukkan pada data (4) berikut.

(4) “... Don't you see that?"

“Apakah kamu tidak menyadarinya?"
Pada data (4), penerjemah memilih kata 'menyadari' sebagai terjemahan dari kata see. Jika diterjemahkan secara harfiah, kata see dalam bahasa sumber seharusnya menjadi 'melihat'. Jika diterjemahkan secara harfiah, ujaran tersebut akan menjadi, "Apakah kamu tidak melihatnya?". Ujaran ini ditujukan untuk Peebee. Dari terjemahan harfiah ini, dengan ujaran sebelumnya yang menyatakan bahwa Peebee, sang tokoh utama dalam cerita kembali mengharapkan hal yang tidak mungkin sehingga kata see tersebut dimaksudkan agar tokoh tersebut 'melihat' lebih dalam dengan kondisi yang sedang dialami sekarang. Kata 'see' yang dimaksud menjadi memiliki makna yang bukan denotatif. Secara konteks, melihat ditujukan agar si tokoh mengerti atau memahami situasi.

\section{Alternatif Frasa}

Alternatif frasa merupakan parafrasa terjemahan pada level frasa yang dilakukan oleh penerjemah sebagai pilihan dalam proses penerjemahan. Parafrasa yang dilakukan dari frasa bahasa sumber dapat berupa frasa dalam bahasa sasaran ataupun klausa. Parafrasa yang tergolong dalam bagian ini dipaparkan sebagai berikut.

(5) "Drizz was overcome with emotion."

"Drizz begitu terharu"

Pada data (5), Drizz yang merupakan salah satu tokoh antagonis kedua dalam cerita ini. Pada bagian ini, dia sedang mendapat kabar gembira dari Pickle sang antagonis pertama tentang rencana yang akan mereka lakukan pada Peebee. Dia sangat senang sehingga dipenuhi dengan emosi (yang menyenangkan). Terjemahan secara harfiah seharusnya menjadi 'Drizz dipenuhi/dikuasai dengan emosi'. Akan tetapi, terjemahan harfiah ini akan menjadi ambigu karena kata 'emosi' masih umum. Penerjemah menerjemahkan dengan 'Drizz begitu terharu' yang membuat kalimatnya menjadi lebih mudah dicerna dan memiliki isi yang sama dengan efek emosi yang diharapkan.

Data parafrasa yang lain dalam penerjemahan buku cerita Peebee Has A Wish yang ditemukan dalam penelitian ini ditunjukkan pada data (6).

(6) "Stinging about the head, and mumbling to himself, Drizz followed Pickle into the house." 
"Dengan sakit yang masih terasa berdenyut di kepala dan sambil menggerutu kepada dirinya sendiri, Drizz mengikuti Pickle ke dalam rumah."

Kalimat ini merupakan bagian lanjutan dari dialog sebelumnya saat Pickle memukul Drizz. Penerjemah menerjemahkan "Stinging about the head, and mumbling to himself ..." dengan "Dengan sakit yang masih terasa berdenyut di kepala dan sambil menggerutu kepada dirinya sendiri..." Penerjemah memberikan tambahan penjelasan lebih pada klausa tersebut dibanding hanya menerjemahkan secara harfiah berikut: 'menyengat di sekitar kepala, dan bergumam pada dirinya sendiri'. Pilihan itu memperjelas kondisi yang terjadi sehingga kalimat tersebut menjadi lebih jelas dan tidak mengambang. Efek yang ingin dicapai pada bahasa sasaran disamakan dengan efek yang ingin dicapai pada bahasa sumber.

Contoh lain ditunjukkan pada data (7) berikut.

(7) ... A deep, inded a very deep sigh escaped from him and he shouted.

... Ia menarik napas dalam-dalam, begitu dalam, lalu berseru.

Pada data (7), alternatif frasa tidak hanya dipakai untuk memberikan alternatif kesepadanan pada level frasa semata, tetapi juga level yang lebih luas, yaitu klausa. Pada data (7), klausa pertama dalam bahasa sumber mengutarakan keluarnya hembusan napas yang panjang dan dalam. Pada bahasa sasaran, fokus terdapat pada seseorang yang melakukan aktivitas penarikan napas yang dalam. Keduanya mengisyaratkan hal yang sama, ada kondisi; (1) seseorang melakukan aktivitas bernapas dan (2) aktivitas bernapas tersebut bukan aktivitas bernapas biasa, tetapi bernapas yang dalam.

Aktivitas bernapas yang dalam itu bahkan mendapat penekanan di kedua bahasa. Pada bahasa sumber, penekanan terdapat pada kata-kata yang dicetak tebal berikut ini a deep, indeed a very deep sigh. Jika diterjemahkan secara harfiah, maka akan menjadi "hembusan napas panjang yang dalam, sungguh sangat dalam." Penekanan dilakukan berulang. Padahal, kata sigh itu sudah merupakan kata yang lebih dalam daripada bernapas biasa, yaitu breath. Ada satu efek yang dibuat karena ada kondisi yang sedang dialami sehingga melakukan aktivitas bernapas panjang seperti itu, apalagi ditambah penekanan-penekan- an melalui kata-kata tambahan di atas. Begitu pula dengan klausa dalam bahasa sasaran. Ada aktivitas bernapas yang dilakukan seseorang. Aktivitas bernapas tersebut bukan aktivitas bernapas biasa, tetapi aktivitas 'bernapas dalam-dalam'. Ada penekanan juga dalam aktivitas bernapas yang tidak biasa tersebut dengan penambahan kata-kata 'begitu dalam'.

Seperti halnya dalam bahasa sumber, aktivitas bernapas seperti yang diutarakan dalam bahasa sasaran juga menandakan satu kondisi tertentu yang dialami orang atau tokoh yang melakukannya. Di sinilah letak kesamaannya, penerjemah mempertahankan efek yang ingin disampaikan dalam pesan bahasa sasaran, meskipun cara penyampaiannya berbeda: hanya sudut pandang yang diubah. Seperti halnya dalam alternatif leksis, dalam alternatif frasa, konteks juga bermain peran penting dalam peralihan pesan yang ada ke dalam bahasa sasaran cerita Harapan Peebee seperti data di bawah ini.

(8) "I hear the most interesting words!..."

$$
\text { "Aku mendengan percakapan yang }
$$

Pada data (8), frasa the most interesting words dalam bahasa sumber diterjemahkan dengan 'percakapan yang begitu menarik'. Tampak penerjemaha tidak ingin melakukan penerjemahan secara harfiah. Hal ini terjadi karena konteks yang terdapat adalah ujaran. Menerjemahkan kata words dengan 'percakapan' justru memberikan kemudahan pemahaman bagi pembaca, khususnya yang awam terhadap budaya bahasa Inggris. Maksud 'kata-kata' yang dimaksud adalah 'percakapan' atau 'perbincangan' sesuai konteks yang ada. Terjemahan 'begitu menarik' diposisikan sebagai terjemahan untuk memberi efek kata 'begitu' yang menandakan hal luar biasa.

Data (9) berikut ini juga diterjemahkan dengan karakteristik yang sama.

(9) “Picking up pickle's mood,...”

"Melihat ulah pickle,.."

Pada data (9), frasa picking up pickle's mood diterjemahkan dengan 'melihat ulah Pickle'. Jika melihat terjemahan secara sekilas, tampak terjemahan tidak sesuai karena pick up sendiri dalam bahasa sumber (bahasa Inggris) bermakna mengambil atau menjemput. Kata mood bermakna 'keadaan jiwa' atau 'suasana 
hati'. Di sisi yang berbeda dengan makna harfiah dari kata-kata yang telah disebutkan, penerjemah justru tidak menerjemahkannya demikian. Akan tetapi, kata-kata dalam bahasa sumber merupakan penghubung untuk disambungkan ke respon dari stimulan yang diutarakan sebelumnya atau berbagai tindakan yang dilakukan oleh Pickle untuk menarik perhatian Peebee. Begitu pula dalam bahasa sasaran, bahasa Indonesia, kata-kata yang digunakan pun disesuaikan untuk menjadi penjembatan antara tindakan-tindakan dan ucapan Pickle untuk dihubungkan dengan respon atas stimulan tersebut.

\section{Alte rnatif Tata Bahasa}

Alternatif tata bahasa merupakan alternatif parafrasa yang terkait dengan terjadinya perubahan tata bahasa dari bahasa sumber ke bahasa sasaran atau dari terjemahan harfiah bahasa sasaran ke parafrasa pilihan bahasa sasaran.

(10) Anyway Peebee himself had no problem with anyone. But the best of his best friends was Oopie the Gaw-gaw and although Oopie was a much smaller bird than Peebee, it was usually Peebee who sat listening to Oopie's stories. Oopie had seen many countries... He didn not care if he was wrong or if he was right or wrong or if he needed what it was he wanted. He did not even care if he wanted something that was impossible to get. Peebee would set of his way... Peebee would immediately set off on his way.

Peebee sendiri tidak memiliki masalah dengan siapapun, tapi teman terbaiknya hanyalah Oopie si Gaw-gaw. Walaupun Oopie hanya seekor burung yang jauh lebih kecil dari Peebee, tapi biasanya Peebee-lah yang duduk mendengarkan cerita-cerita Oopie.

Oopie sudah mengunjungi banyak negeri. Dia banyak membaca dan mendengar sehingga dia menjadi burung yang sangat pintar. Peebee menyukai cerita-cerita Oopie dan bisa duduk berjam-jam mendengarkan kisah petualangan Oopie. Bahkan, kadang-kadang Peebee mendengarkan nasihat Oopie.

Ya, mengherankan karena selama ini, Peebee tidak pernah mau mendengarkan nasihat baik dari Oopie maupun dari yang lain. Tetapi, cerita seperti ini hanya terjadi ketika Peebee menginginkan sesuatu. Dan Saat keinginan itu datang, tak ada yang dapat mengubah pikirannya atau menghentikan langkahnya. Dia tidak peduli apakah tindakannya benar atau salah dan apakah dia benar-benar membutuhkan apa yang diinginkannya atau tidak. Bahkan dia tidak peduli kalau yang diinginkannya itu mustahil untuk diraih. Peebee akan berusaha mendapatkannya dengan caranya sendiri.

Pada data (10), penerjemah membagi paragraf panjang bahasa sumber menjadi tiga paragraf pada bahasa sasaran untuk memudahkan pembaca memahami pesan. Penyampaian cerita dalam bentuk satu paragraf yang begitu panjang dan membutuhkan ingatan. Dalam teks naratif, meskipun paragraf panjang, tidak ada kalimat yang menyimpulkan isi dari paragraf. Di sisi lain, bacaan ini diperuntukkan bagi anak-anak yang masih dalam proses belajar membaca wacana. Dilihat dari segi keterbacaan, kalimat-kalimat yang ada pada teks sumber banyak tergolong ke dalam kalimat yang memiliki tingkat keterbacaan antara baku hingga sangat sulit (Nababan, 7172). Hal serupa banyak terjadi dalam naskah terjemahan. Jika semua dihitung dalam data, maka alternatif ini menjadi alternatif yang paling banyak ditemukan.

Selain perubahan paragraf, perubahan kala waktu juga banyak terjadi dalam terjemahan $\mathrm{Ha}-$ rapan Peebee. Secara umum, cerita narrative dalam bahasa Inggris memakai kala waktu lampau, sedangkan dalam bahasa Indonesia tidak demikian. Hal ini membuat hampir seluruh teks mengalami alternatif tata bahasa.

Data-data lain terkait temuan alternatif tata bahasa disajikan sebagai berikut.

(11) ... Even worse, he forgot everything about the trouble he had just been in....

...Yang lebih buruk lagi, dia melupakan semua masalah yang tengah dihadapinya....

Pada data (11), klausa he had just been in mengalami parafrasa tata bahasa alternatif. Hal tersebut terjadi pada perubahan kala waktu yang terdapat pada bagian terjemahan. Pada bahasa sumber, klausa tersebut berada di kala waktu past participle/perfect atau kejadian sebelum waktu lampau. Jika diterjemahkan secara harfiah, seharusnya menjadi '...yang dia baru saja berada/ 
hadapi'. Namun demikian, pada terjemahan ini, penerjemah mengubahnya menjadi '...yang tengah dihadapinya' dengan kala waktu kejadian yang sedang berlangsung atau dalam bahasa sasaran disebut present progressive tense.

Selain masalah paragraf dan perubahan waktu kejadian dalam kalimat atau ujaran, hal lain yang terdapat dalam alternatif tata bahasa yang ditemukan dalam cerita adalah perubahan kelas kata seperti data (12).

\section{(12) ...And Drizz made a deep,even elegant bow. \\ ... Dan Drizz membungkukkan badannya begitu rendah dan luwes.}

Data (12) menujukkan alternatif parafrasa pada tatanan tata bahasa, yaitu pada kata yang dicetak tebal. Pada bahasa sumber, kata bow yang berarti 'tundukan' merupakan suatu aktivitas yang tergolong nomina, sedangkan dalam bahasa sasaran, kata tersebut berubah menjadi 'membungkukkan' yang merupakan verba atau tindakan yang dilakukan seseorang atau sesuatu.

Perubahan dari kalimat aktif ke kalimat pasif atau sebaliknya juga masuk dalam kategori alternatif tata bahasa. Temuan ditunjukkan pada data (13) berikut.

(13) One must admit that Drizz's great respect for those who showed themselves masters in cheating others had always been healthy.

Harus diakui, rasa hormat Drizz yang besar kepada mereka yang mengaku dirinya sebagai ahli menipu selalu berjalan dengan wajar.

Pada data (13), kata yang dicetak tebal, terjadi perubahan dari kalimat aktif dalam bahasa sumber menjadi kalimat pasif dalam bahasa sasaran.

Temuan lain terkait alternatif tata bahasa dalam Harapan Peebee adalah adanya data perubahan dari kalimat negatif ke positif atau sebaliknya.

(14) "...oh, what would I not give to become a real Blue-wing myself and to dance gracefully in the morning breeze?"

“...Oh, aku akan berikan apapun untuk menjadi Sayap Biru dan menari dengan anggun di udara pagi yang segar seperti ini."
Pada data (14), dengan sudut pandang yang berbeda, penerjemah mengubah klausa yang berbentuk negatif menjadi klausa berbentuk positif.

Berdasarkan paparan data tentang alternatif tatabahasa, terdapat empat karakteristik temuan. Temuan pertama adalah perubahan-perubahan bentuk paragraf yang dipecah menjadi beberapa paragraf atau kalimat yang panjang dibagi menjadi beberapa kalimat. Temuan kedua, perubahan kala waktu. Ketiga, perubahan dari bentuk aktif ke pasif atau sebaliknya. Keempat, perubahan bentuk positif ke negatif atau sebaliknya.

\section{Alte rnatif Gabungan}

Berdasarkan analisis data, ditemukan kompleksitas/tumpang tindih antara satu alternatif dengan alternatif lainnya. Pada kasus ditemukan bahwa gabungan dua atau tiga kategori dalam satu kalimat atau ujaran bisa terjadi. Gabungan tersebut adalah gabungan antara alternatif tata bahasa dan frasa, alternatif frasa dan leksikal, alternatif tata bahasa dan leksikal, serta gabungan ketiganya.

\section{Alternatif Tata bahasa dan Frasa}

Gabungan pertama yang ditemukan adalah gabungan antara alternatif tata bahasa dan alternatif frasa seperti pada data (15) berikut.

(15) ... But as soon as Peebee's Blue-wing story was finished, Oopie said, in a very annoyed manner.

Tapi begitu Peebee menyelesaikan cerita Sayap Birunya, Oopie berkata dengan sangat kesal.

Pada data (15) terdapat dua alternatif. Alternatif pertama adalah alternatif tata bahasa.yang ditandai dengan cetakan tebal. Alternatif ini terjadi karena adanya perubahan dari kalimat pasif ke kalimat aktif. Dalam bahasa sumber, kalimat pasif ditandai dengan subjek kalimat dikenai pekerjaan dan adanya to be 'was' yang diikuti dengan kata past participle (bentuk ketiga dari kata finish). Alternatif lain dalam kalimat ini adalah alternatif frasa yang ditandai dengan tanda garis bawah. Jika bahasa sasaran diterjemahkan secara harfiah, maka frasa tersebut seharusnya menjadi '...dengan sikap yang merasa tergganggu. Terganggu merujuk pada ketidaksukaan Oopie (tokoh yang kesal dalam bahasa sasaran) pada cerita 
dan sikap Peebee yang berulang kali menjengkelkan Oopie.

\section{Alternatif Frasa dan Leksikal}

Gabungan antara alternatif frasa dan leksikal ditemui pada data (16) berikut.

(16) ...Peebee stared at the dancing wonder with wide-open mouth...

...Peebee menatap penari yang menakjubkan itu dengan mulut ternganga.

Pada data (16), terdapat dua alternatif dalam satu kalimat. Alternatif pertama adalah alternatif frasa yang ditandai dengan garis bawah. Jika diterjemahkan secara harfiah, with wide-open mouth akan menjadi 'dengan mulut terbuka lebar'. Di sini, penerjemah menerjemahkan dengan 'dengan mulut menganga'. Frasa 'mulut menganga' dan 'mulut terbuka lebar' menandakan hal yang sama yang mengindikasikan rasa kagum, takjub atau terpana/terpesona yang ditunjukkan secara lebih. Alternatif kedua ditunjukkan dengan dengan kata yang dicetak tebal, yaitu alternatif leksikal. Terjadi perubahan objek dari tarian menjadi pelaku tariannya.

\section{Alternatif Tata Bahasa dan Leksikal}

Gabungan antara alternatif tata bahasa dan leksikal ditunjukkan pada data (17) berikut.

(17) Picking up Pickle's mood, the Great Mastouk played the insulted man of science and screamed,

Melihat ulah Pickle, sang Mastouk Agung memainkan peran ilmuwan yang terhina dan berteriak,

Pada data (17), ada tiga alternatif dalam satu kalimat. Bahkan, ketiga alternatif tersebut menjadi rumit. Alternatif pertama adalah alternatif leksikal yang terdapat dalam terjemahan kata mood yang bermakna 'suasana hari'. Penerjemah menerjemahkannya sebagai 'ulah'. Selain itu, picking up dalam bahasa sumber, bahasa Inggris, jika diterjemahkan secara harfiah seharunya menjadi 'mengambil' atau 'menjemput'. Akan tetapi dalam terjemaan Harapan Peebe, frasa tersebut diterjemahkan menjadi menjadi 'melihat'. Di sisi lain, picking up Pickle's mood merupakan satu kesatuan yang tidak bisa dipisahkan sehingga masuk dalam kategori frasa, bukan leksikal atau kata. Dalam satu kalimat ini saja terdapat tiga alternatif terjemahan yang dimiliki oleh penerjemah.

\section{Alte rnatif Tata bahasa, Frasa dan Leksikal}

Selain dua alternatif dalam satu kalimat atau ujaran, terdapat juga temuan yang menandakan kompleksitas atau kerumitan pembagian alternatif seperti data (18) berikut.

(18) One must admit that Drizz's great respect for those who showed themselves masters in cheating others had always been healthy.

Harus diakui, rasa hormat Drizz yang besar kepada mereka yang mengaku dirinya sebagai ahli menipu selalu berjalan dengan wajar.

Pada kalimat di atas, terjadi alternatif tata bahasa seperti telah dibahas sebelumnya karena terjadi perubahan struktur dari aktif menjadi pasif. Di lain sisi, alternatif parafrasa juga terjadi pada one must admit yang secara harfiah seharusnya diterjemahkan dengan 'seseorang harus mengakui' dengan ada perubahan sudut pandang karena penekanan pada 'pengakuan' dalam bahasa sasaran sehingga kata one pada dihilangkan. Masih pada kalimat yang sama, kata show yang secara harfiah bermakna 'menunjukkan' diubah menjadi 'mengaku'. Kedekatan makna antara 'menunjukkan diri' dengan 'mengaku diri' yang kemungkinan menjadi alasan penggantian kata dari terjemahan harfiah menjadi 'mengaku' dalam hasil terjemahan. Dengan demikian, dalam satu kalimat ini terdapat gabungan tiga alternatif jadi satu, yaitu alternatif tata bahasa, frasa dan leksikal.

\section{Pembahasan}

Dalam paparan hasil penelitian parafrasa dalam terjemahan novel 'Harapan Peebee', parafrasa yang dipakai penerjemah sesuai dengan teori Danielsson (2007), yaitu penyampaian pesan dengan kata-kata yang tidak sama dengan terjemahan harfiahnya. Dari temuan data, semua alternatif muncul dalam sumber data. Akan tetapi, Danielsson tidak menunjukkan bentuk alternatif leksikal maupun kemungkinan-kemungkinan penggunaannya. Penelitian ini memberikan beberapa gambaran mengenai hal tersebut berdasarkan data-data yang ada. 


\section{Alternatif Leksikal}

Berdasarkan data, parafrasa dalam kategori leksikal merujuk pada hal-hal berikut. Pertama, parafrasa memiliki makna yang sama atau tidak terlalu berbeda. Hal ini dapat terlihat pada contoh but yang tidak diterjemahkan 'tapi' atau 'tetapi', melainkan 'hanya saja'. Bagian ini akan mirip dengan prosedur synonymy yang diutarakan oleh Newmark (1998) yang memakai kata-kata yang memiliki kedekatan atau medan makna.

Kedua, parafrasa merupakan kata rujukan atau yang merujuk atau yang dirujuk. Contoh temuan ini adalah data pada alternatif leksikal, yaitu kata that yang diterjemahkan sebagai "nama'. Kata that yang dalam bahasa Indonesia berarti 'itu' adalah kata yang merujuk pada satu nama, yaitu tokoh yang telah disebutkan sebelumnya.

Ketiga, terdapat penyesuaian konteks atau penggantian dengan tetap menjaga konteks atau bisa padanan pragmatik Baker (1992) pada parafrasa. Mengenai padanan pragmatik Baker (1992) dan Haryanti (2013:3) menyatakan bahwa penerjemah perlu mamahami konteks dan koteks yang diterjemahakan untuk mencapainya. Kata that pada temuan ini menunjukkan kegiatan melihat 'rangkaian peristiwa pengalaman buruk Peebee'. Kata see yang mendahuluinya bukan melihat secara fisik, ada proses berpikir di dalamnya. Kata 'menyadari' merupakan proses berpikir.

\section{Alternatif Frasa}

Alternatif frasa dalam penelitian ini memperlihatkan karakteristik berikut. Pertama, parafrasa memiliki makna yang sama atau berdekatan sesuai dengan medan makna dikombiasikan dengan konteks. Seperti halnya dalam alternatif leksikal, dalam alternatif frasa pun, pemakaian parafrasa tetap merujuk pada kedekatan makna. Contohnya adalah kata-kata overcome with emotion yang diterjemahkan dengan 'begitu terharu'. Kata-kata dalam bahasa sumber bermakna harfiah 'dipenuhi dengan emosi'. Kata 'emosi' dapat bermakna luas. Kata 'terharu' masih memiliki kedekatan karena masih bagian dari emosi. Penerjemah memilih kata terharu dengan melihat konteks tokoh yang sedang merasakan rasa haru pada bagian cerita yang berlangsung. Kata 'begitu' memiliki makna yang juga berdekatan dengan 'dipenuhi' karena keduanya menandakan sifat yang lebih atau sangat.
Kedua, tambahan informasi untuk memperjelas (deskripsi). Seperti halnya kesepadanan deskripsi yang diutarakan oleh Newmark (1988) atau teknik deskriptif oleh Molina dan Albir (2002), tambahan deskripsi dalam terjemahan masuk dalam parafrasa dengan kategori alternatif frasa juga. Contoh dari tambahan deskripsi ini dapat dilihat pada contoh terjemahan stinging about the head pada alternatif frasa. Penerjemah mendeskripsikan maksud 'menyengat di sekitar kepala' dengan 'Dengan sakit yang masih terasa berdenyut di kepala' agar pembaca dapat lebih mengerti maksud yang ingin disampaikan.

Ketiga, penggantian dengan efek atau respon yang sama dengan frasa/klausa sumber. Pada alternatif frasa, penerjemah memilih memakai 'melihat ulah Pickle' dalam menerjemahkan picking up Pickle's mood ketimbang terjemahan harfiahnya 'menangkap suasana hati Picle'. Menangkap adalah satu aktivitas yang dilakukan salah panca indera untuk mendapatkan sesuatu. Begitu pula dengan melihat yang merupakan aktivitas yang dilakukan salah satu panca indera untuk mendapatkan sesuatu. Sesuatu yang ditangkap pada frasa ini adalah berupa sesuatu yang tidak bersifat fisik, sedangkan yang didapatkan atau 'ditangkap' dengan mata adalah tingkah laku Pickle. Hal ini disesuaikan dengan konteks kegiatan yang sedang berlangsung saat kalimat tersebut muncul, yaitu tindakan Pickle yang sedang berpura-pura sedih sehingga dia pun merespon dengan hal yang sama. Penyampaian ini tampaknya dekat dengan prosedur modulasi Newmark (1998) yang melihat sudut pandang lain dari pesan yang ingin disampaikan. Dalam hal ini, terlihat betapa konteks sangat berperan dalam proses terjemahan.

\section{Tata Bahasa}

Berdasarkan temuan, parafrasa dengan alternatif tata bahasa memungkinkan ketentuan-ketentuan sebagai berikut. Pertama, memecah paragraf yang terlalu panjang menjadi beberapa paragraf. Sebagai contoh adalah satu paragraf panjang terdiri dari 10 kalimat yang ada di halaman 7 hingga halaman 9 dari buku sumber. Penerjemah memecahnya menjadi 3 paragraf dalam hasil terjemahannya. Selain membagi paragraf panjang menjadi beberapa kalimat, memecah satu kalimat yang panjang menjadi dua atau lebih kalimat juga memungkinkan terjadi. 
Kedua, perubahan waktu. Tidak ada aturan khusus perubahan kala waktu dalam bahasa Indonesia, kecuali dengan penambahan kata sebagai penanda waktu. Data alternatif tata bahasa menunjukkan bahwa he had just been in diterjemahkan 'yang tengah dihadapinya'. Tidak adanya penanda waktu selain tambahan kata dapat menyebabkan perubahan kala waktu dalam hasil terjemahan.

Ketiga, perubahan waktu karena kesesuaian idiom/kewajaran dalam bahasa sasaran. Are you loosing your mind Peebee diterjemahkan dengan 'apakah kamu sudah gila'. Perubahan dari kegiatan yang sedang berlangsung (progressive) menjadi sudah terjadi (perfect).

Keempat, perubahan sudut pandang dapat menjadi alasan atau teknik dalam proses penerjemahan. Hal ini disebut modulasi, baik oleh Newmark (1998) maupun Molina dan Albir (2002). Perubahan sudut pandang atau modulasi dalam temuan penelitian ini menunjukkan indikasi pada dua hal, yakni (1) perubahan dari kalimat pasif ke kalimat aktif atau sebaliknya seperti dalam alternatif kosakata yang menerjemahkan one must admit yang merupakan kalimat aktif menjadi 'harus diakui' yang merupakan kalimat pasif dan (2) perubahan dari kalimat negatif menjadi kalimat positif dan sebaliknya. Contoh dari perubahan ini adalah what would I not give yang merupakan kalimat negatif menjadi 'aku akan berikan apapun' yang merupakan kalimat positif.

Kelima, perubahan kelas kata dapat terjadi dalam parafrasa kategori tata bahasa. Data pada alternatif tata bahasa dapat menjadi contoh bagaimana kata bow (tundukan: kelas kata nomina) di kalimat And Drizz made a deep,even elegant bow dapat berubah menjadi 'membungkukkan' (kelas kata verba) pada kalimat 'Dan Drizz membungkukkan badannya begitu rendah dan luwes'.

\section{Alte rnatif Gabungan}

Danielsson (2007) menyatakan ada kerumitan dan tumpang tindih mengenai alternatifalternatif yang dia ajukan. Dalam temuan ini ditemukan beberapa kerumitan sebagai berikut. Pertama, parafrasa dapat menjadi gabungan-gabungan alternatif. Gabungan ini merupakan kumpul dari (1) dua alternatif, yakni tata bahasa-frasa, frasa-leksikal, dan tata bahasa-leksikal; dan (2) semua alternatif yang ada.

Kedua, sudut pandang/modulasi dapat menyebabkan alternatif gabungan, seperti contoh one must admit menjadi 'harus diakui' yang mengalami perubahan sudut pandang. Perubahan dari kalimat aktif ke kalimat pasif masuk ke dalam kategori alternatif tata bahasa. Di sisi lain, perubahan ini juga merupakan alternatif leksikal karena kata one tidak diterjemahkan.

Ketiga, kesesuaian kewajaran dalam bahasa sasaran dapat menyebabkan alternatif gabungan. Sebagai contoh, 'mulut tenganga' yang merupakan terjemahan dari wide-open mouth lebih wajar ketimbang frasa 'mulut terbuka lebar' karena sesuai dengan konteks, menandakan keterkejutan, atau kekaguman akan sesuatu yang disaksikan. Parafrasa alternatif frasa ini juga sekaligus masuk kategori alternatif tatabahas karena 'ternganga' merupakan kalimat pasif.

Dari temuan-temuan yang telah dipaparkan dapat disimpulkan bahwa parafrasa Danielsson dapat menjadi salah satu pilihan dalam proses penerjemahan, bukan hanya teknik, prosedur ataupun strategi penerjemahan yang sudah ada sebelumnya. Selain itu, diskusi mengenai parafrasa yang merupakan strategi lain dalam proses penerjemahan menjadi sesuatu yang menarik karena penerjemahan pada dasarnya adalah suatu penyampain pesan dengan bahasa atau kata-kata yang berbeda, baik penerjemahan dalam bahasa (intralingual translation) ataupun antar bahasa (interlingual translation).

Secara praktis, temuan mengenai ketentuan proses parafrasa dalam penelitian ini akan membantu para penerjemah untuk melakukan hal yang sama dalam proses penerjemahan. Seperti halnya teori penerjemahan lain, memahami konteks memiliki peran yang sangat penting dalam proses penerjemahan. Temuan dalam penelitian ini yang menunjukkan banyak peran penting konteks dalam parafrasa.

Pembahasan mengenai prosedur, teknik, strategi dan kesepadanan telah banyak dibahas dalam berbagai karya tulis ilmiah penerjemahan. Penelitian-penelitian yang dilakukan terhadap terjemahan karya sasrta anak terkait dengan halhal tersebut juga seolah menjadi perbincangan yang tidak pernah usang. Kasus demi kasus diangkat secara deskriptif oleh para peneliti. Rohana, dkk. (2017) dapat menjadi salah satu contoh dari penelitian mengenai hal ini. Mereka meneliti gaya bahasa, teknik, dan kualitas terjemahan dalam dua dongeng Disney Cinderella: My Bedtime Story dan TinkerBell and The Great Fairy Rescue. Salah satu bagian penting yang didapatnya adalah temuan bahwa teknik kese- 
padanan lazim yang dominan ditemukan pada buku cerita Tinker Bell menyebabkan penambahan, pengurangan atau perubahan baik nomina maupun klausa (Rohana dkk., 20017:161). Selain teknik kelaziman, dengan teori teknik penerjemahan dari Molina dan Albir (2002) juga menemukan teknik-teknik lain yang digunakan pada kedua terjemahan dongeng, meliputi variasi, amplifikasi, trasnposisi, modulasi reduksi, kompresi linguistik, dan teknik peminjaman.

Merujuk pada penelitian-penelitian yang telah ada, dapat diketahui bahwa hasil terjemahan yang merupakan penyampaian pesan lebih didominasi oleh terjemahan yang tidak harfiah. Penerjemahan karya sastra dapat bersifat lentur dan tidak kaku, seperti pada terjemahan kata perkata ataupun harfiah. Pilihan untuk lebih berorientasi pada pembaca sasaran menjadi sangat penting dalam terjemahan, khususnya terjemahan karya sastra. Sebagai contoh, kita dapat melihat penelitian yang dilakukan oleh Fadly (2016) mengenai ideologi penerjemahan budaya dalam terjemahan karya sastra 'Negeri 5 Menara'. Penelitian yang dilakukannya merujuk pada teori Venuti (2005) mengenai ideologi penerjemahan: pengasingan dan pelokalan. Dalam terjemahannya di The Land of 5 Towers, penerjemah menunjukkan keberpihakannya pada pembaca sasaran dengan hasil temuan berupa ideologi pengasingan. Hal ini dapat dilihat dari sedikitnya jumlah prosedur transferensi dan naturalisasi yang hanya berjumlah tujuh data dari 90 data yang ada dengan memakai prosedur penerjemahan Newmark (1998). Prosedur yang paling banyak dipakai adalah prosedur fungsional yang mengadaptasi terjemahan dengan kata-kata yang bersifat netral. Dengan demikian, terjadi perubahan-perubahan dalam hasil terjemahannya.

Keberpihakan pada bahasa sasaran dan pembaca sasaran dapat membuat penejemah tidak menerjemahkan secara harfiah, namun menggunakan cara penyampaian yang berbeda. Seperti halnya penelitian-penelitian tersebut, penelitian mengenai parafrasa ini juga menunjukkan hal yang sama bahwa penerjemahan karya sastra,

\section{DAFTAR PUSTAKA}

Baker, M. 1992. In Other Words: A Coursebook on Translation. London \& New York: Routledge.

Corens, R. 2008. Harapan Peebee. Diterjemahkan oleh Faisal Riyadi dan Redy Kuswanto. Jakarta: Erlangga. khususnya yang ditujukan bagi anak akan lebih membuat penerjemah memilih untuk lebih sering menggunakan penyampaian yang berbeda, bukan penerjemahan harfiah. Jika dalam penelitian-penelitian tersebut, atau banyak penelitian lain, menjadikan prosedur atau teknik atau strategi seperti prosedur Newmark sebagai acuan, penelitian ini, dengan mendasarkan pada parafrasa Danielsson (2007), memaparkan cara parafrasa digunakan dalam penerjemahan. Parafrasa dalam hal ini bukan sebagai salah satu prosedur yang diusulkan oleh Newmark, tetapi lebih pada penyampaian yang berbeda dari terjemahan harfiah.

\section{SIMPULAN}

Dari hasil temuan, penerjemah melakukan terjemahan parafrasa di semua kategori. Dari ketiga alternatif, kategori alternatif frasa merupakan kategori yang paling banyak ditemukan. Meskipun demikian, pembagian klasifikasi internal dalam masing-masing alternatif yang ditemukan dalam data menandakan bahwa alternatif tata bahasa merupakan alternatif yang memiliki paling banyak subkategori dikarenakan tata bahasa yang berbeda serta sudut pandang yang ingin dibawakan oleh penerjemah dalam proses penerjemahannya. Di satu sisi, ada temuan lain yang menandakan adanya kondisi kalimat atau ujaran yang memiliki lebih dari satu kategori alternatif. Kategori-kategori tersebut bisa bercampur satu dengan lainnya dalam satu kalimat atau ujaran. Ditambah dengan adanya kompleksitas dalam pembagian kategori. Pemahaman pada konteks juga banyak menjadi bagian penting dalam temuan ini. Pada akhirnya, pilihan parafrasa terletak pada penerjemah itu sendiri.

\section{UCAPAN TERIMA KASIH}

Penulis menyampaikan ucapan terima kasih kepada mitra bestari (reviewers) yang telah memberikan saran, kritik, dan rekomendasi perbaikan artikel ini.

Corens, R. 2007. Peebe Has A Wish. Jakarta: Erlangga.

Danielsson, P. 2007. In Other Words: Using Paraphrases in Translation. Translating And The Computer 29. Proceedings of the Twenty-ninth Interna- 
tional Conference on Translating and the Computer, 29-30 November 2007, London. Online, http://www.mt-archive.info/05/Aslib2007-Daniels son.pdf, diakses: 18 Juni 2017

Darma, Y. A. 2007. Metode Pembelajaran Penerjemahan. Jurnal Pendidikan dan Kebudayaan, 67: $178-195$

Fadly, A. 2016. Ideologi dalam Penerjemahan Budaya: Pada Novel Terjemahan "Negeri 5 Menara" Karya Ahmad Fuadi. Jurnal Pendidikan Bahasa dan Sastra, 16 (2): 132-143.

Haryanti, D. 2013. Pergeseran Kategori Nomina dan Verba dalam Linguistics Accross Cultures dan Linguistik di Pelbagai Budaya. Linguistik Indonesia, 25 (1): 41-57.

Hoed, B. 2006. Penerjemahan dan Kebudayaan. Jakarta: Pustaka Jaya.

Molina, L. \& Albir, A. H. 2002. Translation in Technique and Revisited: A Dynamic and Functional Approach.: Translator Journal, 47 (4): 498-512.

Nababan, M. R. 2003. Teori Menerjemah Bahasa Inggris. Yogyakarta: Pustaka Belajar.
Newmark, P. 1988. A Textbook of Translation. Hertfordshire: Prentice Hall International.

Newmark, P. 1991. About Translation. Clevedon: Longdunn Press, Ltd.

Nida, E. 1964. Toward a Science of Translation. Leiden: E. J. Brill.

Nord, C. 1991. Text Analysis in Translation: Theory, Methodology, and Didactic Application of a Model for Translation-Oriented Text Analysis. Atlanta: Rodopi.

Rohana, Y., dkk. 2017. Gaya Bahasa, Teknik Penerjemahan, dan Kualitas Terjemahan dalam Dongeng Disney Dwibahasa Berjudul Cinderella: My Bedtime Story dan Tinkerbel and The Great Fairy Rescue. Prasasti: Journal of Linguistics, 2 (1): 150-166.

Venuti, L. 1995. The Translator's Invisibility: A History of Translation. London: Routledge.

Wechsler, R. 1998. Performing Without A Stage: The Art of Literary Translation. North Haven: Catbird Press. 